\title{
SOCIAL DEVELOPMENT
}

Editorial note. This publication is part of a series of articles dedicated to the 25th anniversary of the ISEDT RAS foundation. It presents the results of the long-term research in the formation of children's health. The study, initiated and supervised by ISEDT RAS Director, Doctor of Economics, Professor V.A. Ilyin, is a pioneer in Russian social science. The monitoring data are reflected in the dissertation research of A.A. Shabunova (Study of children's health: monitoring method (case study of the Vologda Oblast): Ph.D. in Economics Dissertation. Moscow, 2003; Public and individual health in modern Russia: state and trends: Doctor of Economics. Moscow, 2011).

DOI: $10.15838 / \mathrm{esc} / 2015.2 .38 .7$

UDC 316.42, LBC 65.524.1

(C) Shabunova A.A.

\section{Twenty years of children's health monitoring: organization, results, conclusions}

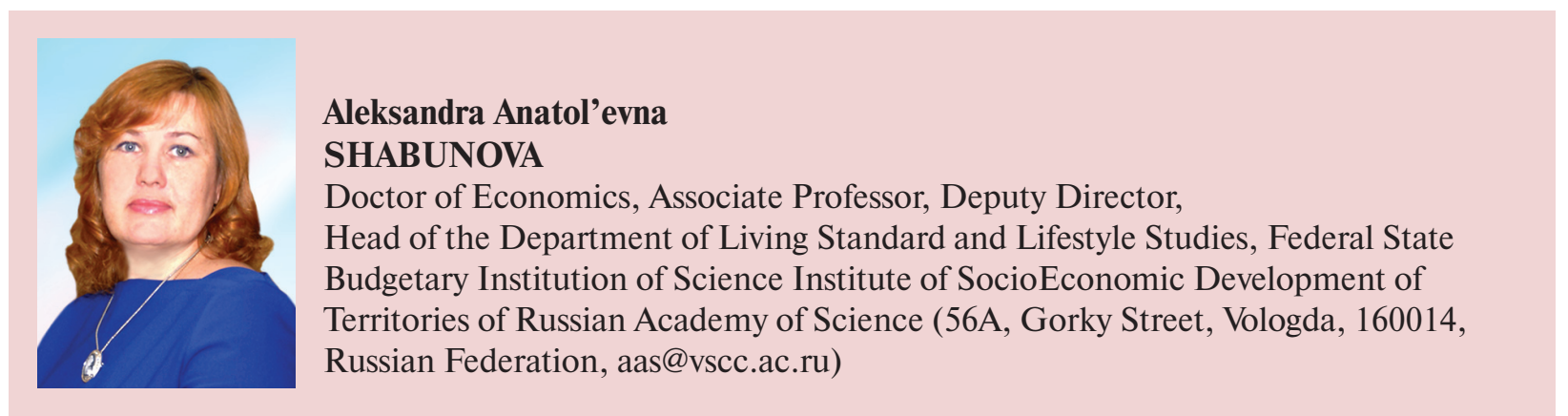

Abstract. Deep understanding of human potential reproduction, presenting it as a continuous cycle and reflecting the continuity of generations, is significant for the formation of health and development of children. Today's children will determine the future of Russian society. It is they who in 10-15 years will be a major part of the labor and creative population, a demographic base of the country. The research into children's problems through the prism of socio-economic development helps identify targets of the state many-sided policy. The article presents results of the long-term medical sociological monitoring on the formation of child health carried out by the Institute of Socio-Economic Development of Territories of RAS with the support of the Vologda Oblast Healthcare Department since 1995. The special monitoring study of health dynamics in real time is unique not only for the Vologda Oblast, but for Russia as well. It reveals the transformation of a personality and the dependence of these changes on direct and indirect factors. 
The work's feature is that it addresses an extremely important and wide range of issues: whether man was born healthy or not, if he/she is unhealthy, then why and why he/she was born unhealthy; whether his/her health after the birth is improving or deteriorating; if health is changing, what causes the changes. The 15 year observations disclose the dynamics of child health in the conditions of transformation processes taking place in the country. If the official statistics only records certain health trends, the monitoring results allow us to talk about them at a qualitatively new level. They reveal the underlying causes of demographic processes. The conclusion is, on the one hand, obvious and, on the other hand, it can not be neglected: economic stability and orderly development of the social sphere are critical for family well-being and child health. The reverse situation leads to the destruction of the family institution, the decrease in child population and the reduction in its quality characteristics. The second conclusion, according to the study results, is that we identify risk factors for child health empirically. The obtained data are used at the legislative level and are of great interest in the scientific community. On the example of certain families we show how the child's health is affected by a lifestyle of his/her parents, conditions of education, welfare, medical activity, diet, housing conditions, environmental conditions. Nowadays all of these factors require careful attention of not only authorities, but also the parents.

The child's health monitoring also results in the further development of scientific areas and the formation of new thematic research units, such as the "Monitoring of reproductive health and behavior of the population" and the "Reproductive potential of the region" and later the "Reproduction of the population: trends and reserves".

Key words: monitoring; children's health; public policy; health factors; human potential.

\section{History research}

The preservation and strengthening of the population's health as national wealth and the factor determining the state of human potential is the critical task of society. The demographic and socioeconomic situation in Russia in the late 20 th - early 21 st century is characterized by the intersection of two independent processes: on the one hand, demographic, characterized by active aging of the population and transition to innovative environmental technologies.

Meanwhile, the "field" of childhood, its human and social potential of is decreasing. Over the past 15 years the number of children aged $0-17$ has decreased by almost 12 million, or about one third, thereby "cutting off" the scale of the youth (18-30 years old) of the next age stage. Today's children will determine the future of Russian society. It is they who in 10-15 years will be a major part of the labor and creative population, a demographic base of the country. The study of children's problems through the prism of socioeconomic development helps identify the targets of a diversified policy of the state.

In the 1980s the Russian science elaborated the idea to carry out a comprehensive monitoring of health and development of children. Natal'ya Mikhailovna Rimashevskaya, Doctor of Economics, Professor, RAS Corresponding 
Member, Honored Scientist of Russia, suggested the need to conduct studies similar to English ones ${ }^{1}$. The idea was realized only in May 1995 in the Vologda Oblast. The Institute of Socio-Economic Development of Territories of RAS together with the Institute of Socio-Economic Studies of Population of RAS under the auspices of the Vologda Oblast Government has been conducting a longitudinal (longterm) panel study of socio-economic and medical factors affecting health and development of children for over 20 years.

The research is aimed at revealing the impact of the environment on health and development of a child. This question is considered at two levels: how quality characteristics of the children's generation change in terms of the socio-economic situation in the country and the region and how health of children changes in the context of the family life dynamics. Family can not but experience hardships of the changes taking place at the state

1 In the UK the first stage of the monitoring was carried out in March 3-9, 1958 and was named "national child development study" (NCDS). Seventeen thousand children born March 3-9, 1958 were selected as a study object. The main goal of this survey was to obtain reasonably accurate information about the number of children born with irregularity or dying in the perinatal period. The researchers collected maximum available information about a mother, a father of a newborn, but also about a child and his/her first week of life. The results of the first stage were used to develop the national strategy for infant mortality reduction. The second stage of the survey (NCDS -2 ) included the supervision of all members of the cohort until the age of 7 . The results of this stage revealed the factors influencing not only health but also various indicators of child development. The observation of children at the third stage of the survey (until the age of 14) (NCDS - 3) helped assess their intellectual potential. In 1981 when the study participants reached the age of 23, the fourth stage of the research was carried out. It reflected the possibilities of their professional skills and employability. level. Therefore, we are convinced that the real situation can be assessed due to comprehensive information: data of the intensive monitoring and official statistics ${ }^{2}$.

To achieve the goal, we have selected the longitudinal (long-term) monitoring of cohorts, which reflects all the changes in child health in different periods of life. The sample consists of all families in which children were born in May 1995 in Vologda, Cherepovets and the district centers of Veliky Ustyug, Kirillov and the urban-type settlement of Vozhega (the cohorts of 1998, 2001, 2004 and 2014 are also presented). The observation allows us to obtain realtime objective and reliable information about health and development of children and the factors that determine them.

The Vologda Oblast Healthcare Department has been interested in this project since the early stages of its implementation. Close cooperation of scientists and managers in this project has contributed to the study and influenced the management decisions.

During the monitoring its results has become more and more significant, requiring deeper interpretation. Looking back, we can say that the initial potential of the child health monitoring has been unleashed 20 years later. Today it is clear that the data identified in the research is timely, relevant and innovative. They open broad prospects for the preservation and strengthening of human potential.

2 Rimashevskaya N.M. Rossiiskii genofond: kachestvo budushchikh pokolenii [The Russian Gene Pool: the Quality of Future Generations]. Narodonaselenie [Population], 2000, no. 4 , p. 100 . 
We sincerely appreciate the support of those who 20 years ago saw the potential in the study, believed in our strength and took part in the monitoring.

First of all, we are grateful to RAS Corresponding Member Doctor of Economics Natal'ya Mikhailovna Rimashevskaya and the scientific staff of the Institute of Socio-Economic Studies of Population of RAS (ISESP RAS) for the idea of monitoring, its promotion and the assistance we have been receiving throughout the study period; Doctor of Economics, Professor Elena Borisovna Breeva, who has supervised the study at ISESP RAS long. We express gratitude to Director of the Institute of SocioEconomic Development of Territories of RAS Doctor of Economics Professor Vladimir Aleksandrovich Ilyin, who started conducting the monitoring in the Vologda Oblast and to date contributes to its implementation.

We thank the Vologda Oblast Government, the Department of Healthcare and personally Ph.D. in Medicine Aleksandr Andreevich Kolin'ko and Ph.D. in Medicine Elena Leonidovna Vologdina, who have been supervising the research study and promoting the use of its results at the legislative level. Of course, we express appreciation to the doctors, nurses, parents who participated in the study, gave us with an opportunity to observe their families and, hopefully, received considerable benefit from it.
We can highlight an important research achievement: the parents taking part in the study note that they have begun to look at the formation of their child's health differently. The participation in the monitoring has motivated may people to rethink their role in the upbringing of children, change their lifestyle. And, as a result, we have received many words of gratitude from real people noticing improvement in health of their children, normalization of relations with them, more favorable psychological atmosphere in the family.

\section{Data collection methods}

The longitudinal panel study of demographic, socio-economic and health factors influencing children's health in the Vologda Oblast started in May 1995². The fifth wave of the monitoring was carried out in 2014.

To date, the study involves five cohorts of families (children of 1995, 1998, 2001, 2004 and 2014 year of birth) that expands the possibilities to identify and analyze the trends in health and development of children and the factors contributing to these processes (tab. 1).

3 The study included all families, in which children were born within two weeks (May 15-30, 1995). The survey was conducted in the cities of Vologda, Cherepovets, the district centers of Kirillov, Veliky Ustyug and the urban-type settlement of Vozhega. Since 2004 the study has involved 4 cohorts of families, in which children were born in the periods of May 15-30, 1995, March 1-25, 1998, 2002 and 2004 in the same settlements. The information was taken four times a year during the first year of life (infants, children under the age of 1 month, 6 months and 12 months) and then annually. 
Table 1. Monitoring stages

\begin{tabular}{|c|c|c|}
\hline $\begin{array}{c}\text { Year of the beginning } \\
\text { of the study }\end{array}$ & $\begin{array}{c}\text { Period of the beginning } \\
\text { of the study }\end{array}$ & $\begin{array}{c}\text { Number of studied } \\
\text { families }\end{array}$ \\
\hline 1995 & May 15 - May 30 & 100 \\
\hline 1998 & March 1 - March 25 & 200 \\
\hline 2001 & March 1 -March 25 & 200 \\
\hline 2004 & March 1 -March 25 & 200 \\
\hline 2014 & March 1 - March 21 & 370 \\
\hline
\end{tabular}

Monitoring is conducted by completing specially designed questionnaires. The research involves the use of complex tools, such as:

1. Questionnaires characterizing the features of families and households of a newborn (filled in by parents). The questionnaire includes the following main information blocks: socio-demographic (gender, age, household composition, age of parents, social class); level of family life, labor activity of child's parents (education, profession, job position, conditions and nature of work in the period before child birth, per capita income, estimated characteristics of family income); housing conditions (size of residential space, qualitative characteristics of housing and property); evaluation of environmental conditions, conditions and quality of a mother's diet during pregnancy and of a child; bad habits of parents (drinking of alcohol, smoking); medical factors: parents' self-assessment of health (presence of contraindications to the birth of a child, chronic diseases of parents, planning to have a baby, state of health during pregnancy); characteristics of pregnancy and childbirth - filled in by medical workers, according to the documentation (the presence of deviations in health of women during pregnancy, medical activity of a pregnant woman, length and nature of childbirth, presence of additional obstetric events); assessment of health of a newborn baby by a neonatologist (weight, height, Apgar test, identified diseases, group of health filled in by obstetrician-gynaecologists on the basis of medical documentation).

2. Questionnaires characterizing health and development of a child, life conditions at 1 and 6 months, 1, 2 and 3 years of age, etc. (the questionnaire consists of two parts: the first includes the evaluation of living conditions and development of children, filled in by parents; the second the characteristics and assessment of child's health, filled in by local pediatricians).

3. It is very important to have information about the attitude of children towards their health, their understanding of life values. Therefore, since 2005 children have been participating in the survey in the framework of this project. Questionnaires help summarize information about selfreported health and development of children, their hobbies and interests (filled in by children aged 10 and over). 


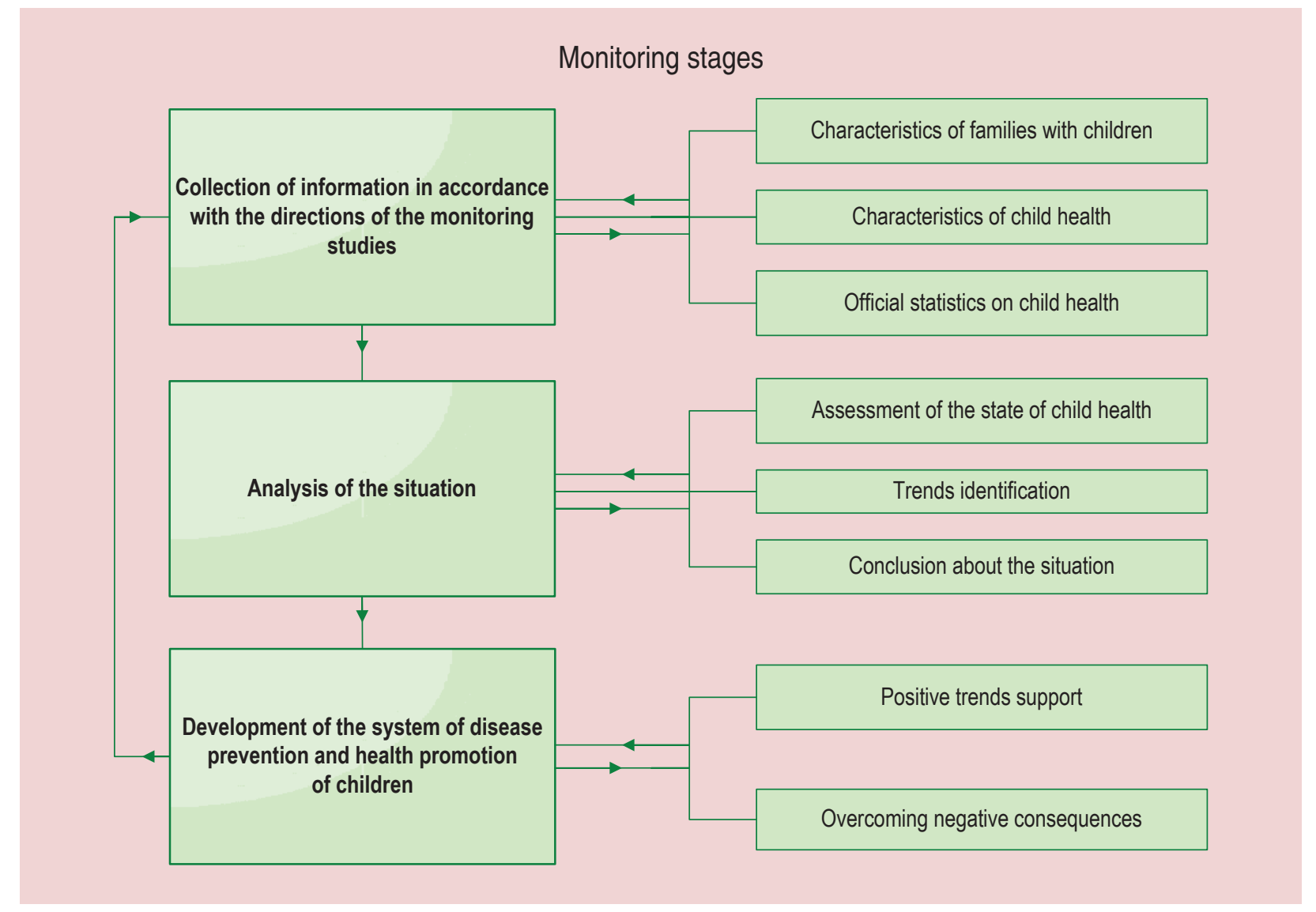

The heads of pediatric departments, pediatricians, nurses, teachers and parents help us conduct the monitoring of conditions to form a healthy generation was carried out by. The awareness of this study usefulness and the enthusiasm, shown by the experts, has contributed to the successful outcome of the experiment.

The conducted monitoring study of children's health helps identify common structural units and their interconnections that can be used in other areas of the country with regard to regional features (figure).

The proposed system to carry out monitoring provides a methodological basis for the study of direct and indirect mutual influence of territorial socio-economic development on children's health and potential of child population's health economic development of the territory in the near and distant future.

\section{Main results of the monitoring}

The analyzed monitoring data indicate the declined potential of children's health, got at birth, and the gradual health deterioration. The main critical periods of childhood are determined: the first year of life (among infants the proportion of healthy children and children with minimal risk of health loss is $60-40 \%$, by a year it drops to $20-15 \%$ ), between the 
ages of 6 and 7 (the share of children with chronic diseases increases by $5-6 \%$ at average). They are associated with the most important moments of social adaptation. At the age of 12 , due to the physiological characteristics, the immune system of children strengthens and the share of those having cold-related diseases decreases. However, the incidence of musculoskeletal apparatus and gastrointestinal tract diseases goes up, visual acuity goes down, i.e., the number of chronic pathologies rises. We consider particularly alarming the weakened attention of medical personnel to the category of children with Health Group 2. Often children are considered healthy only because they seldom go to the doctor.

The new research phase in 2014 showed that almost $15 \%$ of the newborns had good health (classified as Health Group 1), that is by 5-10 p.p. higher than in previous years of the study. At the same time, the share of children with functional and some morphological abnormalities (Group 2B, by 6 p.p. compared to 2004) decreased. These processes are connected, on the one hand, with the improvement of socio-economic state of the population, on the other hand, with the measures of demographic policy in the country and the region.

The gender analysis of children's health shows that girls have better health than boys. In each surveyed cohort the proportion of girls that have Health Group 1 is greater than that of boys during the observed period. At the same time, the proportion of boys who have chronic diseases, higher than the corresponding proportion among girls.
The territorial differences are vivid: according to the doctors' estimates, health of children in the cities of Cherepovets and Vologda are worse than in the districts. The proportion of children with chronic diseases in cities is by $2-4$ times higher than in the districts. But this can be caused not only by better health of children in rural areas, but also by lower detectability of diseases there than in large cities. Rural areas lack pediatricians. The insufficient number of medical specialists leads to late and incomplete detection of chronic diseases in children.

The analysis helps identify the factors that have a statistically significant impact on children's health. The effects are not the same in different age periods. In early childhood the medical-biological factors and lifestyle of a mother influence children's health greatly:

- Poor health of parents. So, mothers of healthy children have good or excellent health in $65 \%$ of the cases and mothers of unhealthy children - only in $51 \%$; mothers of unhealthy children more often have satisfactory health (43\%) more likely than healthy people $(35 \%)$.

- Low level of hemoglobin of women during pregnancy. Among the mothers suffering from anemia during pregnancy only $29 \%$ of children were born healthy. By the age of 1 the proportion of children with Health Group 1 decreases to $8 \%$, by the age of $2-$ up to $7 \%$ and by the age of $3-$ slightly more than $1 \%$. At the same time, among the diseases prior to or developed during pregnancy anemia had the major share $(35 \%)$ in 1995-2007. 
- Maternal smoking increases the risk of low birth weight infants with poor health; among smoking women only $3-14 \%$ of children were born with normal weight. According to the monitoring data, $27 \%$ of women smoked before pregnancy and $12 \%$ during pregnancy.

- Conditions of a future mother's work that do not meet sanitary standards. In the 1995 cohort mothers of sick children more often worked in conditions of dust $(12.5 \%$ against $8.8 \%$ of mothers of healthy children), elevated temperature $(12.5 \%$ against $2.9 \%)$, mental stress (37.5\% against $29.4 \%$ ), night time (12.5\% against $1.5 \%$ ). This factor is widely distributed.

- Infantfeeding character affects health not only in early childhood but also in subsequent periods. According to the monitoring, children who are breastfed up to 6 months are ill by 2 times less compared to children having artificial nutrition. However, the prevalence of breastfeeding is small in Russia: in 2008 only $41 \%$ of infants were breastfed up to 6 months and $39 \%$ - up to 1 year.

During the formation of children's health in preschool and school age, other factors are important. The environment risks and the level of family life increase, the impact of biological factors reduces. There are most significant factors, such as:

- Weakened health of children in the first year of life raises the risk of developing chronic diseases later. Children that do not have diseases during the first year of life, do not have chronic diseases at the age of 5 , while among children, who are ill at the age of 2, $10 \%$ have a chronic disease at the age of 5 and $30 \%$ at the age of 8 .

- Low family incomes limit the abilities of children nutrition as well as prevention and strengthening of their health. The survey data prove that the insufficient and unbalanced nutrition of children can result in diseases, and parents can not afford necessary medicine due to financial constraints. The risk factors that lead to deteriorated health of children are concentrated in the families with low incomes. Despite the fact that in 20002008 wages increased, $20 \%$ of children under 16 lived in poverty.

- Poor housing, microclimate discomfort (cramped conditions, uncomfortable temperature, humidity, dust) involve lower resistance to environmental effects, low immunity. It is a prerequisite for the frequent occurrence of respiratory and allergic diseases. More than half of the families rate their living conditions as satisfactory in the study; however, 13-18\% of the respondents indicate that they live in poor or requiring capital repair houses and apartments. The evaluation of housing conditions did not change significantly in 1995-2008.

Unsatisfactory environmental conditions in the neighborhood. So, in the 1998 cohort $33 \%$ of the children living in favorable environmental conditions and $17 \%$ - in the poor conditions had good health. On average, $28 \%$ of the children (according to their parents) live in poor or very poor conditions. The assessment of environmental conditions did not change significantly in 1995-2008. 
Table 2. Prevalence of risk factors in the population

\begin{tabular}{|l|l|}
\hline \multicolumn{1}{|c|}{ Factors } & \multicolumn{1}{c|}{ Prevalence in the population } \\
\hline Poor health of a mother & $\begin{array}{l}\text { In } 2014 \text { in the Vologda oblast 8\% of the women of reproductive age assess their health as } \\
\text { bad or very bad; } 43 \% \text { - as satisfactory (according to the monitoring data*) }\end{array}$ \\
\hline $\begin{array}{l}\text { Low level of hemoglobin of a woman during } \\
\text { pregnancy }\end{array}$ & $33 \%$ of the unhealthy pregnant women have anemia \\
\hline Maternal smoking & $\begin{array}{l}\text { Prevalence of smoking among pregnant women increased significantly (from 3\% in 1995 } \\
\text { to 10\% in 2014). In the Vologda Oblast 29\% of the women of reproductive age smoke. } \\
\text { Their share increases. } \\
\text { (ibidem) }\end{array}$ \\
\hline $\begin{array}{l}\text { Conditions of a future mother's work that do } \\
\text { not meet sanitary standards }\end{array}$ & $\begin{array}{l}\text { In the Vologda Oblast in 2006, 26\% of the women worked in the conditions that did } \\
\text { not meet sanitary norms, while in 2000 this figure did not exceed 7\% (according to the } \\
\text { Territorial Body of the Federal State Statistics Service in the Vologda Oblast). }\end{array}$ \\
\hline $\begin{array}{l}\text { Low family incomes } \\
\text { About 20\% of the children under 16 live in poverty. In this period the families participating } \\
\text { in the monitoring give more positive evaluations of their purchasing power. The share of } \\
\text { the respondents who have enough funds for all current expenses increases from } 27 \% \text { to } \\
38 \% . \text { The number of families, who believe that money is only enough for daily expenses, } \\
\text { but it is difficult to buy clothes and other things, decreases from 53 to } 37 .\end{array}$ \\
\hline $\begin{array}{l}\text { Poor housing } \\
13-18 \% \text { of the families participating in the monitoring live in poor or requiring capital } \\
\text { repair houses and apartments }\end{array}$ \\
\hline $\begin{array}{l}\text { Unsatisfactory environmental conditions in } \\
\text { the neighborhood }\end{array}$ & $\begin{array}{l}28 \% \text { of the children (according to their parents) live in poor or very poor environmental } \\
\text { conditions }\end{array}$ \\
\hline $\begin{array}{l}\text { * Monitoring of public health has been conducted by ISEDT RAS annually since 1999. The polls are held in the cities of Vologda and } \\
\text { Sherepovets and in eight districts (Babaevsky, Velikoustyugsky, Vozhegodsky, Gryazovetsky, Kirillovsky, Nikolsky, Tarnogsky and }\end{array}$ \\
\hline
\end{tabular}

- Low level of socio-hygienic literacy and health-saving activity of parents. The analyzed monitoring data reveal the following: (a) parents' activity aimed at preserving children's health as they get older decreases; b) parents often assess children's health inadequately, their children do not follow diet and do not go to a doctor in time; however, this could prevent the development of chronic diseases. According to the medical specialists, $18-23 \%$ of the children require diet, while it is followed in $2-5 \%$ of the families.

The prevalence of the above risk factors is quite high. Only $6 \%$ of the families can be considered as healthy, the rest have these factors in various combinations.
Two risk factors are observed in more than one-third of the families, three factors in about $20 \%$. The highest proportion of healthy children is identified in the families where the negative effects are absent or minimal (about 30\%). The highest share children with a chronic disease is in the families characterized by four $(25 \%)$ and five $(33 \%)$ risk factors. The risk factors are concentrated in the families with low incomes.

Using the data of the child health monitoring and other sociological studies, we assess the prevalence of identified risk factors in the population ( $t a b .2)$.

The obtained data indicate the formation of a specific pattern: the prevalence of risk 
factors in the population leads to the deterioration of children's health, and this, in turn, determines the low level of young people's health and ultimately affects adults' health. Poor health of the parents causes poor health of children. The so-called social funnel" 4 forms and drags young cohort into it: health problems move from older age groups to children and young people.

\section{Conclusions}

The stated above show that there are no prerequisites for the significant enhancement of children's health in Russia in the short term and it is necessary to actively promote and strengthen children and adolescents' health, a basis for the formation of reproductive and labor potential and human capital at the state and family level.

In the last decade the Russian Federation has been taking some pains to maintain and improve health of the population, including children (the national project "Health; regional target programs; the Program for healthcare modernization). Nevertheless, the analysis of the causes for the decline in children's health and major risk factors indicates the insufficiency of the current measures. It is advisable to continue and modernize existing measures and develop new ones. The main directions of preventive work are the following:

1. Increased responsibility for compliance with health standards at organizations

4 Rimashevskaya N.M. Sotsial'no-ekonomicheskie i demograficheskie problemy sovremennoi Rossii [SocioEconomic and Demographic Problems of Modern Russia]. Vestnik Rossiiskoi akademii nauk [Herald of the Russian Academy of Sciences], 2004, vol. 74, no. 3, pp. 209-218. and enterprises; betterment of legislation to improve working conditions, especially for pregnant women.

2. Raising living standard of the population as a whole, primarily, of families with children. The current state support is insufficient. It is important to increase the allowance for child care up to the level of the average wage of a mother. The benefit can be paid on a parity basis by the state and the enterprise (at the place of work of a mother or a father).

3. Greater opportunities for young families in terms of housing acquisition and housing conditions betterment due to improvement of mortgage mechanisms (the modern mechanism is not suitable for most young families raising children). Business involvement in the construction of departmental, corporate housing, perhaps, share-based with its subsequent repurchase by employees.

4. The decline in smoking prevalence among the population. Strengthening control over the implementation of legislation regulating tobacco smoking. Creation of "tobacco-free zones" in the municipalities, development of the volunteer movement among teenagers. Making explanatory videos about the impact of nicotine on mother and child's health and demonstrating them in antenatal clinics, family planning centers, in conversations with teenagers.

5. Tightening of the state control over the enterprises' observance of environmental norms. Reducing traffic congestion of highways in major cities. Wide spread of household appliances, mitigating the 
impact of aggressive environment: air purifiers, water purifiers.

Single measures taken in the framework of state programs and projects are not systemic and do not give proper result. To maintain and improve health of the Russians it is necessary to develop a national strategy for the preservation of public health, suggesting a systemic problem-oriented approach to solving this task.

$$
* * *
$$

Further development of the scientific direction is another important result of the child health monitoring. In 2004 by the initiative and with the support of the Vologda Oblast Healthcare Department we launched the research in reproductive health of the population, which was based on the monitoring of the conditions of child health formation. The monitoring reveals that parents' health, in particular reproductive, has a significant impact on children's health and timely diagnosis and correction of its state and prevention help reduce the loss of public health potential. The results of this stage are presented in the monograph "Reproductive potential of the population in the region: state, trends, prospects" and the thesis by M.A. Lastochkina. The works systemize and summarize the accumulated data of the child health monitoring and construct econometric models of reproductive potential of the population in the region.

In 2005 the mass survey of the population was conducted to get additional data and the study of reproductive behavior of the population in the gender aspect was launched.

In 2006-2014 the monitoring of reproductive health and behavior of the population continued. Its results help identify the determinants of reproductive choice and offer an organizational mechanism to regulate reproductive behavior for the formation of "new" social norms of childbearing and the creation of conditions to implement reproductive plans of the population. In 2013, on the basis of this monitoring, Ph.D. thesis in Economics was prepared and defended by O.N. Kalachikova.

In 2010-2015 the scientific school "Problems of socio-demographic development of territories" was created under the supervision of Doctor of Economics A.A. Shabunova. Its development has contributed to studies of public health.

\section{References}

1. Elliott J., Vaitilingam R., Elliott J. Now We Are 50: Key Findings from the National Child Development Study. 2008. Available at: http://www.cls.ioe.ac.uk/studies.asp?section=0001000200030003

2. Vliyanie roditelei na otnoshenie podrostkov k kureniyu (roditel'skii faktor) [The Influence of Parents on Adolescent Attitudes to Smoking (Parental Factor)]. 2002. Available at: http://www.youth-non-smoking. ru/Programs/Program4/ParentsStudy/\#2 
3. Gosudarstvennyi doklad o sostoyanii zdorov'ya naseleniya i deyatel'nosti zdravookhraneniya Vologodskoi oblasti v 2007 godu [Governmental Report on the State of Population's Health and Health Activities of the Vologda Oblast in 2007]. Under editorship of Ph.D. in Medicine A.A. Kolin'ko. Vologda: DZO, 2008. $158 \mathrm{p}$.

4. Demograficheskii ezhegodnik Rossii 2009: stat. sb. [Demographic Yearbook of Russia 2009: Statistics Digest]. Rosstat [Federal State Statistics Service of the Russian Federation], Moscow, 2009. 525 p.

5. Dokhody, raskhody i potreblenie v domashnikh khozyaistvakh Vologodskoi oblasti v 1997-2008 gg. (po materialam vyborochnogo obsledovaniya byudzhetov domashnikh khozyaistv): stat. byulleten' [Revenues, Expenditures and Consumption of Households in the Vologda Oblast in 1997-2008 (Based on the Sample Survey of Households' Budgets): Statistics Newsletter]. Vologdastat [Territorial Body of the Federal State Statistics Service in the Vologda Oblast], Vologda, 1998-2010.

6. Zhuravleva I.V. Zdorov'e podrostkov i okruzhayushchii mir [Health of Adolescents and Surrounding World]. Moscow: IS RAN, 1997.

7. Kislitsina O.A. Zhilishchnye usloviya i zdorov'e [Housing Conditions and Health]. Obshchestvennoe zdorov'e i profilaktika zabolevanii [Public Health and Disease Prevention], 2006, no. 6, pp. 39-45.

8. Mirovaya statistika zdravookhraneniya. 2009 god [World Health Statistics. 2009]. Geneva: Vsemirnaya organizatsiya zdravookhraneniya, 2009. 150 p.

9. Rimashevskaya N.M. Rossiiskii genofond: kachestvo budushchikh pokolenii [The Russian Gene Pool: the Quality of Future Generations]. Narodonaselenie [Population], 2000, no. 4, p. 100.

10. Rimashevskaya N.M. Sotsial'no-ekonomicheskie i demograficheskie problemy sovremennoi Rossii [Socio-Economic and Demographic Problems of Modern Russia]. Vestnik Rossiiskoi akademii nauk [Herald of the Russian Academy of Sciences], 2004, vol. 74, no. 3, pp. 209-218.

11. Reproduktivnyi potentsial naseleniya regiona: sostoyanie, tendentsii, perspektivy [Reproductive Potential of the Population of the Region: State, Trends and Prospects]. Team of authors under the supervision of Doctor of Economics, Professor V.A. Ilyin. Vologda: VNKTs TsEMI RAN, 2005. 208 p.

12. Statisticheskii ezhegodnik Vologodskoi oblasti: stat. sb. [Statistical Yearbook of the Vologda Oblast]. Vologdastat [Territorial Body of the Federal State Statistics Service in the Vologda Oblast], Vologda, 2010-2013.

13. Statisticheskii ezhegodnik Rossiiskoi Federatsii [Statistical Yearbook of the Vologda Oblast]. Rosstat [Federal State Statistics Service of the Russian Federation], Moscow, 2009-2013.

\section{Cited works}

1. Elliott J., Vaitilingam R., Elliott J. Now We Are 50: Key Findings from the National Child Development Study. 2008. Available at: http://www.cls.ioe.ac.uk/studies.asp?section=0001000200030003

2. The Influence of Parents on Adolescent Attitudes to Smoking (Parental Factor). 2002. Available at: http:// www.youth-non-smoking.ru/Programs/Program4/ParentsStudy/\#2

3. Governmental Report on the State of Population's Health and Health Activities of the Vologda Oblast in 2007. Under editorship of Ph.D. in Medicine. A.A. Kolin'ko. Vologda: DZO, 2008. 158 p.

4. Demographic Yearbook of Russia 2009: Statistics Digest. Federal State Statistics Service of the Russian Federation, Moscow, 2009. 525 p.

5. Revenues, Expenditures and Consumption of Households in the Vologda Oblast in 1997-2008 (Based on the Sample Survey of Households' Budgets): Statistics Newsletter. Territorial Body of the Federal State Statistics Service in the Vologda Oblast, Vologda, 1998-2010.

6. Zhuravleva I.V. Health of Adolescents and Surrounding World. Moscow: IS RAN, 1997. 
7. Kislitsina O.A. Housing Conditions and Health. Public Health and Disease Prevention, 2006, no. 6, pp. 39-45.

8. World Health Statistics. 2009. Geneva: Vsemirnaya organizatsiya zdravookhraneniya, 2009. 150 p.

9. Rimashevskaya N.M. The Russian Gene Pool: the Quality of Future Generations. Population, 2000, no. 4 , p. 100.

10. Rimashevskaya N.M. Socio-Economic and Demographic Problems of Modern Russia. Herald of the Russian Academy of Sciences, 2004, vol. 74, no. 3, pp. 209-218.

11. Reproductive Potential of the Population of the Region: State, Trends and Prospects. Team of authors under the Guidance of Doctor of Economics, Professor V.A. Ilyin. Vologda: VNKTs TsEMI RAN, 2005. 208 p.

12. Statistical Yearbook of the Vologda Oblast. Territorial Body of the Federal State Statistics Service in the Vologda Oblast, Vologda, 2010-2013.

13. Statistical Yearbook of the Vologda Oblast. Federal State Statistics Service of the Russian Federation, Moscow, 2009-2013. 